Research Article

\title{
Profitability and Resource Use Efficiency of Rice Production in Jhapa District of Nepal
}

\author{
Sanjiv Subedi ${ }^{*}$, Yuga Nath Ghimire ${ }^{1}$, Meena Kharel${ }^{1}$, Bimala Sharma1, \\ Jiban Shrestha ${ }^{2}$, Bidya Kiran Sapkota ${ }^{3}$
}

\author{
${ }^{1}$ Nepal Agricultural Research Council, National Agricultural Policy Research Centre, Khumaltar, Lalitpur, Nepal. \\ ${ }^{2}$ Nepal Agricultural Research Council, National Plant Breeding and Genetics Research Centre, Khumaltar, Lalitpur, Nepal. \\ ${ }^{3}$ Agriculture and Forestry University, Rampur, Chitwan, Nepal
}

\begin{tabular}{|c|c|}
\hline Article Information & Abstract \\
\hline $\begin{array}{l}\text { Received: } 20 \text { September } 2020 \\
\text { Revised version received: } 12 \text { October } 2020 \\
\text { Accepted: } 16 \text { October } 2020 \\
\text { Published: } 29 \text { October } 2020 \\
\text { Cite this article as: } \\
\text { S. Subedi et al. (2020) Int. J. Soc. Sc. Manage. 7(4): } \\
\text { 242-247. DOI: 10.3126/ijssm.v7i4.32487 } \\
\text { *Corresponding author } \\
\text { Sanjiv Subedi, } \\
\text { Nepal Agricultural Research Council, National } \\
\text { Agricultural Policy Research Centre, } \\
\text { Khumaltar, Lalitpur, Nepal } \\
\text { Email: sanjiv.subedi@ gmail.com } \\
\text { ORCID: https://orcid.org/0000-0002-8084-008X }\end{array}$ & $\begin{array}{l}\text { This research was conducted from January to June, } 2020 \text { to determine the } \\
\text { profitability and resource use efficiency of rice production in Jhapa district of } \\
\text { Nepal. The primary information was collected from } 100 \text { rice growing farmers, } \\
\text { randomly selected from the sampling frame, using the pre-tested semi-structured } \\
\text { interview schedule; moreover, two Key Informant Surveys were also done. In } \\
\text { addition, the secondary information was collected from the review of related } \\
\text { literatures. Descriptive statistics, Cobb-Douglas production function were used for } \\
\text { data analysis. The gross margin (NRs. } 53,531 / \mathrm{ha} \text { ) and benefit cost ratio }(2.05) \\
\text { indicated that rice production was profitable with the productivity of } 4.5 \mathrm{mt} / \mathrm{ha} \text {. The } \\
\text { return to scale of rice production was calculated } 0.86 \text { which indicated that the } \\
\text { production function exhibited a decreasing return to scale. The allocative efficiency } \\
\text { indices revealed that for optimum allocation of resources, cost on seed, chemical } \\
\text { fertilizers and irrigation cum pesticides/herbicides need to be increased by } 73.8 \text {, } \\
78.4 \text { and } 93.9 \text { percent respectively; while cost on human labor and tractor power } \\
\text { should be decreased by } 53.8 \text { and } 51.5 \text { percent respectively. }\end{array}$ \\
\hline $\begin{array}{l}\text { Peer reviewed under authority of IJSSM } \\
\text { () } 2020 \text { IJSSM, Permits unrestricted use under the } \\
\text { CC-By-NC license. } \\
\text { OPEN ACCESS } \\
\text { This is an open access article \& it is licensed under a } \\
\text { Creative Commons Attribution Non-Commercial } 4.0 \\
\text { International } \\
\text { (https://creativecommons.org/licenses/by-nc/4.0/) }\end{array}$ & \\
\hline & \\
\hline
\end{tabular}

\section{Introduction}

Rice (Oryza sativa L.) is the major staple food crop of Nepal which ranks the first among cereal crops in terms of area $(1,491,744 \mathrm{ha})$, production $(5,610,011 \mathrm{mt})$ and productivity (3.76 mt/ ha) (MoALD, 2020). Moreover, it is the foremost staple food for more than $50 \%$ of the world's population (Fageria, 2007). Rice is the member of the Poaceae family and out of twenty three species of rice, only two species of rice have been known for their commercial value. These two 
species are Oryza sativa (Asian rice) and Oryza glaberrima (African rice) among which Oryza sativa is the most important commercial species of rice (CDD, 2015).

Agriculture and forestry sector contribute more than one fourth $(28 \%)$ share in the national Gross Domestic Product (GDP) of Nepal. Rice is the most important agricultural crop of Nepal having highest contribution to Agriculture Gross Domestic Product (AGDP) and livelihood of the people. Rice is grown in three distinct major agroecological zones, which are Terai and Inner Terai (60-900 masl), Mid hills (900-1,500 masl) and Mountains/High hills (1,500 - 3,050 masl). Moreover, Terai accounts for more than two third of the country's rice output; Jhapa is the Terai district having highest rice production in Nepal. Also, Jhapa is the first 'rice superzone' of Nepal declared by Prime Minister Agriculture Modernization Project (PM-AMP); nearly 1000 hectares of land are required for a super zone (MoAD, 2016). The area, production and productivity of rice in Jhapa district has been reported 85,879 ha, 365,845 $\mathrm{mt}$ and $4.26 \mathrm{mt} / \mathrm{ha}$ respectively (MoALD, 2020).

The cost of rice production is increasing due to the increase in cost of inputs such as: chemical fertilizers, seeds, labor, farm machineries and other resources Also, the farmers have inadequate knowledge on resource optimization due to which they can't use the resources at the economic optimum level. The ultimate aim of any farmer or agricultural farm is to maximize the profit and minimize the cost with the efficient use of resources. With the irrational and inefficient use of inputs, there will be wastage of time, money and effort; also, the output and profit declines. This will ultimately be led to weak economy of the agricultural household and country. Sapkota, Joshi, Kattel and Bajracharya (2018) estimated the resource use efficiency of maize seed production in Palpa district of Nepal. Moreover, Dhakal et al. (2015) also estimated the resource efficiency of mustard production in Chitwan district of Nepal. Rice being the major staple food crop of Nepal, estimation of costs, benefits, allocative efficiency indices of rice production need to be done. In this context, this study aims to assess the profitability and resource use efficiency of rice production in Jhapa, the district having the highest rice production in Nepal.

\section{Methodology}

\section{Study Area}

Jhapa district was purposely selected for the study as it has the highest rice production in Nepal and is the first rice super zone district declared by PM-AMP, MoALD. The major rice growing areas of Jhapa from Gauradaha municipality, Gaurigunj rural municipality, Birtamod municipality, Arjundhara municipality and Kanchankawal rural municipality were selected for the purpose of the study, having consultation with the agricultural officials of rice super zone and the local government.

\section{Sampling Procedure and Data Collection}

The simple random method of sampling was used to select the sample from the sampling frame of the rice growing farmers of the study area, obtained from the concerned agricultural officials. A pre-tested interview schedule was used to collect the primary information; in addition, two Key Informant Surveys were performed. Also, relevant literatures were reviewed for the secondary information. Altogether, 100 samples were taken for the purpose of the study.

\section{Methods and Techniques of Data Analysis}

Data entry and analysis were done using the computer software packages like: Statistical Package for Social Science (SPSS), STATA and Microsoft Excel (MS-Excel) based on the suitability of the data. The following analyses were performed.

\section{Cost and Return Analysis}

The benefit cost analysis was done after calculating the total cost and gross return from the rice cultivation. Cost of production was calculated by summing the variable cost items such as: seed cost, fertilizer cost, human labor cost, tractor and thresher cost and others like cost of herbicides and pesticides, irrigation cost incurred in the production process. For calculating gross return, income from product sales (grains, straw) were accounted. Following Dillon and Hardaker (1993), return from rice grains was calculated by multiplying the total volume of output by the average price at harvesting period. In a similar manner, the return from the straw was calculated. Finally, the gross return was calculated by summing the returns from the grain and straw.

\section{Gross Margin}

The gross margin was calculated by deducting the total variable cost from gross return. Gross margin calculation was done to have an estimate of the difference between the gross return and variable costs. Gross margin was calculated by using the method as given by Olukosi et al. (2006) using following formula;

Gross Margin (NRs./ha) = Gross return (NRs./ha) - Total variable cost (NRs./ha)

\section{Benefit Cost Ratio}

The undiscounted benefit cost ratio was estimated as a ratio of gross return and total variable cost. The benefit cost ratio was calculated by using the formula:

Benefit cost ratio $(\mathrm{BCR})=\frac{\text { Gross return }}{\text { Total variable cost }}$

The above formula to calculate the BCR has also been used in the studies, Dhakal et al., 2015 and Subedi et al., 2019.

\section{Cobb-Douglas Production Function}

It has been revealed that Cobb-Douglas production function is useful in computation of marginal value product (MVP) which is the important component to determine optimum, 
over and underuse of resources (Gujarati, 2009). The CobbDouglas production function of the following form was fitted to examine the resource productivity, efficiency and return to scale.

$\mathrm{Y}=\mathrm{aX}_{1}{ }^{\mathrm{b} 1} \mathrm{X}_{2}^{\mathrm{b} 2} \mathrm{X}_{3}^{\mathrm{b} 3} \mathrm{X}_{4}^{\mathrm{b} 4} \mathrm{e}^{\mathrm{u}}$

Transformed to linear form for ease in computation by taking logarithm on both sides, we have,

$\ln Y=\ln a+b_{1} \ln X_{1}+b_{2} \ln X_{2}+b_{3} \ln X_{3}+b_{4} \ln X_{4}+u$

Where,

$\mathrm{Y}=$ Gross return from rice production (NRs./ ha)

$\mathrm{X}_{1}=$ Seed cost $(\mathrm{NRs} . / \mathrm{ha})$

$\mathrm{X}_{2}=$ Chemical fertilizer cost (NRs./ ha)

$\mathrm{X}_{3}=$ Human labor cost (NRs./ ha)

$\mathrm{X}_{4}=$ Tractor and thresher cost (NRs./ ha)

$\mathrm{u}=$ Random disturbance term or error term

$\mathrm{a}=$ Intercept or constant term

$\mathrm{e}=$ Base of natural logarithm

$\ln =$ Natural logarithm

$b_{1}, b_{2}, b_{3}$ and $b_{4}=$ Coefficients of respective variables.

The return to scale of rice production was calculated by summing the coefficients of all the explanatory variables estimated from the linearized Cobb-Douglas production function. Dhakal et al. (2015) had also calculated the return to scale in a similar manner.

The allocative efficiency of a resource used was estimated taking the ratio of Marginal Value Product (MVP) of variable input and the Marginal Factor Cost (MFC) for the input and tested for its equality to one. Taking reference of Goni et al. (2007), the resource use efficiency was calculated using the formula;

$\mathrm{r}=\mathrm{MVP} / \mathrm{MFC}$

Where,

$\mathrm{r}=$ Efficiency ratio,

$\mathrm{MVP}=$ Marginal value product of a variable input; $\mathrm{MFC}=$ Marginal factor cost

Furthermore,

$\mathrm{MVP}=\mathrm{dy} / \mathrm{dx}$, which is the product of regression coefficient with ratio of geometric mean of gross return to the level of use of respective resource.

Again, following (Mijindadi, 1980), the relative percentage change in MVP of each resource required to obtain optimal resource allocation, i.e. $\mathrm{r}=1$ or $\mathrm{MVP}=\mathrm{MFC}$ was estimated using the equation below;

$\mathrm{D}=(1-\mathrm{MFC} / \mathrm{MVP}) \times 100$
Or, $\mathrm{D}=(1-1 / \mathrm{r}) \times 100$

Where,

$\mathrm{D}=$ absolute value of percentage change in MVP of each resource

$\mathrm{r}=$ efficiency ratio

\section{Results and Discussion}

\section{Cost of Rice Production}

The total cost of rice production was calculated NRs.50901/ha. Human labor cost was the major cost item having the highest share in the total cost $(63.44 \%)$ followed by chemical fertilizers $(13.41 \%)$, tractor power $(12.70 \%)$, seed $(8.44 \%)$ and irrigation cum pesticides/ herbicides $(2.01 \%)$ (Table 1). In line of this finding, Sapkota, Chaulagain, Dutta and Subedi (2018) also reported human labor as the major cost attributing item having the share of $77.7 \%$ in the total variable cost in rice production in Naghlebhare rice block, Kathamndu. The human labors were found to be used in the farming activities such as: nursery bed preparation, transplanting, application of fertilizers, herbicides and pesticides, intercultural operations, harvesting and packaging.

Table 1: Average cost of rice production

\begin{tabular}{llll}
\hline S.N. & Costs items & $\begin{array}{l}\text { Mean } \\
\text { (NRs./ha) }\end{array}$ & $\begin{array}{l}\text { Percentage } \\
\text { of total cost }\end{array}$ \\
\hline 1. & Seed & 4298 & 8.44 \\
2. & Chemical Fertilizers & 6827 & 13.41 \\
3. & Human labour & 32294 & 63.44 \\
4. & Tractor power & 6459 & 12.7 \\
5. & Irrigation cum & 1023 & 2.01 \\
& pesticides/ & & \\
& herbicides & & \\
\hline & Total variable cost & 50901 & 100 \\
\hline Source: Field survey, 2020 &
\end{tabular}

\section{Returns from Rice Production}

The average total returns from rice production per hectare was calculated NRs.1,04,432; the share of grains was $90 \%$ while that of straw was $10 \%$ (Table 2). Adhikari (2011) reported that the average total returns from rice production in Chitwan district of Nepal was NRs. 66597.07/ha that is accounted from grain (85\%) and straw (15\%).

Table 2: Average returns from rice production

\begin{tabular}{|c|c|c|c|}
\hline S.N. & $\begin{array}{l}\text { Return } \\
\text { items }\end{array}$ & $\begin{array}{l}\text { Mean } \\
\text { (NRs./ha) }\end{array}$ & $\begin{array}{l}\text { Percentage of total } \\
\text { returns }\end{array}$ \\
\hline 1. & Grain & 93989 & 90 \\
\hline 2. & Straw & 10443 & 10 \\
\hline & $\begin{array}{l}\text { Total } \\
\text { returns }\end{array}$ & 104432 & 100 \\
\hline
\end{tabular}

\section{Price and Productivity}

The average productivity of rice was calculated $4.5 \mathrm{mt} / \mathrm{ha}$. The report published by MoALD (2020) also showed the rice productivity of Jhapa to be $4.3 \mathrm{t} /$ ha while the national average productivity has been estimated $3.8 \mathrm{mt} / \mathrm{ha}$. The 
average price of rice grain in the study area was calculated NRs. 23/kg. The average rice cultivated land was calculated 1.64 ha; Ranjeet, Ramdhan, Sarna and Sukkha were the mostly cultivated varieties in the study area.

\section{Gross Margin and Benefit Cost Ratio}

The gross margin of rice production in the study area was calculated NRs. 53531/ha. The benefit cost ratio was estimated 2.05; which mean if 1 rupee is invested; it will give 2.05 rupees returns. The positive value of gross margin and benefit cost ratio being greater than one indicates the financial viability of rice production in the study area (Table 3 ). In line of this finding, the benefit cost ratio of rice production in the eastern development region has been reported 1.9 while that of Nepal 1.8 (Joshi, 2011). Moreover, Sapkota, Chaulagain, Dutta and Subedi (2018) also reported the benefit cost ratio 1.9 in rice production at Naghlebhare rice block, Kathmandu.

Table 3: Financial indicators of rice production in the study area

\begin{tabular}{ll}
\multicolumn{1}{c}{ Indicators } & Average value \\
\hline Total variable cost & NRs. 50901/ ha \\
Total returns & NRs. 1,04,432/ ha \\
Gross margin & NRs. 53,531/ ha \\
Benefit cost ratio & 2.05 \\
\hline Source: Field survey, 2020 &
\end{tabular}

\section{Cobb-Douglas Production Function}

The $F$ value, $F(5,94)=13.87$, Prob $>F=0.0000$ showed the stability of the overall regression equation and joint significant at $1 \%$ level. The value of the coefficient of multiple determination, $\mathrm{R}$ square $\left(\mathrm{R}^{2}\right)$ was estimated 0.42 which indicated that 42 percent of variation in the total rice income was explained by the explanatory variables included in the model. The mean Variance Inflation Factor (VIF) is 1.41 and none of the variables had VIF greater than 1.56, which indicates that there is no such multicollinearity between the independent variables which could affect the interpretations that the model has revealed. The BreuschPagan test for heteroscedasticity showed a constant variance of errors, which indicated the model has no heteroscedasticity. Also, the regression coefficient error test (RESET) confirms the model had no omitted variables (Table 4).

It has been revealed that out of five independent variables included in the model, three variables have statistically significant effect on the income from rice production; they are: chemical fertilizers cost ( $1 \%$ level of significance), human labor cost (5\% level of significance), irrigation cum pesticides/herbicides cost (10\% level of significance). With the increase in chemical fertilizers cost, human labor cost and irrigation cum pesticides/herbicides cost by $1 \%$, the income from rice production increases by 30, 20 and $16 \%$ respectively (Table 4). Wongnaa and Ofori (2012) also reported the significant positive contribution of labor, fertilizer and pesticide on the production of cashew in Ghana. Moreover, Dhakal et al. (2015) also revealed that the human labor cost, fertilizers cost and irrigation cum pesticide cost positively and significantly affect the income from mustard production in Chitwan, Nepal.

Table 4: Estimated value of coefficients and related statistics of Cobb-Douglas production function of rice production

\begin{tabular}{llll}
\hline Variables & Coefficients & Standard error & T value \\
\hline Seed cost & 0.16 & 0.119 & $1.362(0.176)$ \\
Chemical fertilizer cost & $0.30 * * *$ & 0.087 & $3.463(0.001)$ \\
Human labor cost & $0.20 * *$ & 0.078 & $2.514(0.014)$ \\
Tractor power & 0.04 & 0.074 & $0.510(0.611)$ \\
Irrigation cum pesticides/ herbicides cost & $0.16 *$ & 0.092 & $1.736(0.086)$ \\
Constant & $1.77 * * *$ & 0.430 & $4.105(0.000)$ \\
\hline
\end{tabular}

*** Significant at $1 \%$ level;** Significant at 5\% level ; * Significant at $10 \%$ level

Note: Figure in parentheses indicates $\mathrm{P}$ value.

\begin{tabular}{ll}
\hline Summary Statistics & \\
\hline Number of observation(N) & 100 \\
R square & 0.42 \\
Adjusted R square & 0.39 \\
F value & $\mathrm{F}(5,94)=13.87$, Prob $>\mathrm{F}=0.0000$ \\
Variance Inflation Factor (VIF) & $1.41($ mean VIF) \\
Heteroscedasticity & $\mathrm{Chi}^{2}(1)=0.00$, prob $>$ chi $^{2}=0.96$ (constant variance) \\
Model has no omitted variables (ovtest) & $\mathrm{F}(3,91)=1.93$, Prob $>\mathrm{F}=0.13$ \\
Return to scale & 0.86 \\
\hline \multicolumn{1}{c}{ Source: Field survey, 2020 }
\end{tabular}

Source: Field survey, 2020 
Table 5. Estimates of measures of allocative efficiency of inputs used in rice production

\begin{tabular}{|c|c|c|c|c|c|c|c|}
\hline Inputs & $\begin{array}{l}\text { Geometric } \\
\text { mean }\end{array}$ & Coefficient & MVP & MFC & $\mathbf{R}$ & Efficiency & $\begin{array}{l}\text { Percent } \\
\text { adjustment } \\
\text { required (D- } \\
\text { value) }\end{array}$ \\
\hline Seed cost & 4206 & 0.16 & 3.82 & 1 & 3.82 & Underused & 73.8 \\
\hline Chemical fertilizer cost & 6498 & 0.3 & 4.64 & 1 & 4.64 & Underused & 78.4 \\
\hline Human labor cost & 30789 & 0.2 & 0.65 & 1 & 0.65 & Overused & 53.8 \\
\hline Tractor power & 6093 & 0.04 & 0.66 & 1 & 0.66 & Overused & 51.5 \\
\hline $\begin{array}{l}\text { Irrigation cum } \\
\text { Pesticides/herbicides }\end{array}$ & 982 & 0.16 & 16.37 & 1 & 16.37 & Underused & 93.9 \\
\hline
\end{tabular}

The return to scale (sum of the regression coefficients of all the inputs) of rice production was calculated 0.86 which indicated that the production function exhibited a decreasing return to scale; implies that if all the inputs specified in the function are increased by $1 \%$, income from rice production will increase by $0.86 \%$. The results are in line of the findings of Obasi (2007), Wosor and Nimoh (2012) and Rabbani et al. (2013) who have reported decreasing return to scale on arable crops, chilli and mustard production respectively. Also, Gani and Omomona (2009) reported decreasing return to scale $(0.961)$ on small scale irrigated maize producers in Nigeria. In contrary to these findings, Wongnaa and Ofori (2012) and Goni et al. (2007) reported increasing return to scale on cashew and rice production respectively in Ghana and Nigeria.

\section{Estimation of Resource Use Efficiency}

The estimated Marginal Value Product (MVP) and efficiency ratios of different inputs used in rice production were presented in table 5 . The efficiency ratio of the inputs: seed (3.82), chemical fertilizers (4.64) and irrigation cum pesticides/herbicides (16.37) were greater than one indicating their underuse while that of human labor (0.65) and tractor power (0.66) were less than one which indicated the overuse. This showed that the inputs were not allocated efficiently.

For optimum allocation of resources, cost on seed, chemical fertilizers and irrigation cum pesticides/herbicides need to be increased by 73.8, 78.4 and $93.9 \%$ respectively; while cost on human labor and tractor power should be decreased by 53.8 and $51.5 \%$ respectively (Table 5 ). The opportunity of doing adjustment in seed cost could be well utilized by purchasing quality improved seeds which gives high yield; similarly, the dose and quantity of quality chemical fertilizers, irrigation cum pesticides/herbicides should be increased by the farmers as per the estimates of resource use efficiency. Moreover, the cost on human labor could be decreased by introducing low cost mechanization while the tractor power cost could be decreased by adopting minimum tillage technologies.

In line of the findings of this study, Sapkota, Joshi, Kattel and Bajracharya (2018) also reported the underutilization of seed and fertilizer, overutilization of human labor and tractor power in maize seed production in Palpa district of Nepal. Similar results of underutilization of seed and fertilizer has also been reported by Gani and Omonana (2009) on the production of maize in Nigeria. Also, Dhakal et al. (2015) has reported that the seed, fertilizer and irrigation cum pesticides were underutilized in mustard production in Chitwan; but the results are on the contrary with the findings for adjustment on human labor and tractor labor in the same study. However, in line of the findings of this study, Ghimire and Dhakal (2014); Danso-Abbeam, Dahamani and Bawa (2015) revealed the overutilization of human labor in their studies. Also, the findings regarding underutilization of seed and chemical fertilizer is synonymous to the results of Sharma (2009); Ojo, Salami and Mohammed (2008) but contradict with Chapke, Mondal and Mishra, (2011).

\section{Conclusion}

This study showed that the rice production was financially viable; it's a profitable enterprise. Also, Jhapa district was found to be highly productive and potential area for rice production. Despite this, it has been revealed that the inputs used in rice production were inefficiently utilized. For the optimum allocation of resources, cost on seed, chemical fertilizers and irrigation cum pesticides/herbicides need to be increased whereas cost on human labor and tractor power should be decreased. Thus, if rational uses of resources could be ensured, rice production would be an economically more viable commercial enterprise with increased profitability and food availability.

\section{Acknowledgements}

The authors would like to thank Nepal Agriculture Research Council (NARC) for providing the fund to accomplish this study. They would like to express their gratitude to their colleagues and heartiest thanks owed to the respondents of the study area for giving the valuable information.

\section{Author's Contribution}

S. Subedi designed the research plan. S. Subedi, M. Kharel and B. Sharma collected the data; B.K. Sapkota designed a data entry template in MS excel and entered the data. S. Subedi analyzed the data and prepared the manuscript. Y.N. Ghimire provided comments and feedback to finalize this 
manuscript. Final form of manuscript was approved by all authors.

\section{Conflict of Interest}

The authors declare that there is no conflict of interest with present publication.

\section{References}

Adhikari RK (2011) Economics of organic rice production. The Journal of Agriculture and Environment 12: 297-103.

CDD (2015) Rice Varietal Mapping in Nepal: Implication for Development and adoption. Hariharbhawan, Kathmandu: : Ministry of Agricultural Development.

Chapke RR, Mondal B and Mishra JS (2011) Resource-use efficiency of sorghum (Sorghum bicolor) production in rice (Oryza sativa)-fallows in Andhra Pradesh, India. Journal of Human Ecology 34(2): 87-90.

Danso-Abbeam G, Dahamani AM and Bawa GA (2015) Resource-use-efficiency among smallholder groundnut farmers in Northern Region, Ghana. American Journal of Experimental Agriculture 6(5): 290-304.

Dhakal SC, Regmi PP, Thapa RB, Sah SK and Khatri-Chhetri DB (2015) Resource use efficiency of mustard production in chitwan district of Nepal. International Journal of Applied Sciences and Technology 3(4): 604-608.

Dillon JL and Hardaker JB (1993) Farm management research for small farm development. Food and AgricultureOrganization of the United Nations, Rome.

Fageria N (2007) Yield physiology of rice. Journal of Plant Nutrition 30: 843-879.

Gani BS and Omonona BT (2009) Resource use efficiency among small scale irrigated maize producers in Northern Taraba State of Nigeria. J. Human Ecol. 28(2): 113-119.

Ghimire B and Dhakal SC (2014) Production Economics of Sustainable Soil Management Based Cauliflower (Brassica oleracea L. Var. Botrytis) in Dhading District of Nepal. American Journal of Agriculture and Forestry 2(4): 199-205.

Goni M, Mohammed S and Baba BA (2007) Analysis of resource use efficiency in rice production in the Lake Chad area of Borno State, Nigeria. J. Sust. Devt. in Agri. and Envt. 3(2): 31-37.

Gujarati DN (2009) Basic econometrics. Tata McGraw-Hill Education.

in Rupandehi district, Nepal. M.Sc. Thesis, IAAS, Rampur, Chitwan, Nepal. pp. 40-44.

Joshi NP, Maharjan KL and Piya L (2011) Production Economics of Rice in Different Development Regions of Nepal. Journal of International Development and Cooperation 17(1): 103-112.
Mijindadi NB (1980) Production efficiency on farms in northern Nigeria. PhD dissertation. Cornell University, USA.

MoAD (2016) Prime Minister Agriculture Modernization Project (PMAMP) Final Cabinet Document. Ministry of Agricultural Development, Government of Nepal, Singhadarbar, Kathmandu, Nepal.

MoALD (2020) Statistical Information on Nepalese Agriculture 2018/2019.Agri Statistics Section, Monitoring, Evaluation and Statistics Division. Singha Durbar, Kathmandu, Nepal: Ministry of Agricultural Development.

Obasi PC (2007) Farm size and productivity relationship among arable crop farmers in Imo state, Nigeria. Int. J. Agri. And Rural Devt 9(91): 91-99. DOI: 10.4314/ijard.v9i1.2673

Ojo MA, Salami AE and Mohammed US (2008) Profitability, inputs elasticities and resource-use efficiency in small scale cowpea production in Niger state, Nigeria. Journal of Agriculture and Social Research 8(2): 125-130

Olukosi JO, Isitor SU and Ode MO (2006) Introduction to agricultural marketing and prices: principle and application. American J. Agri. and Forestry 2(4): 199205.

Rabbani MG, Sheema AA, Islam MS and Hasan HK (2013) Profitability and resource use efficiency of mustard production: evidence of farmers' practices in Mymensingh District of Bangladesh. Int. J. App. Research in Business Admin. and Econ. 2(3): 37-46.

Sapkota BK, Dutta JP, Chaulagain TR and Subedi S (2018) Production and marketing of rice in Naghlebhare rice block, Kathamndu: an economic analysis. Nepalese Journal of Agricultural Sciences 16: 145-155

Sapkota M, Joshi NP, Kattel RR and Bajracharya M (2018) Profitability and resource use efficiency of maize seed production in Palpa district of Nepal. SAARC J. Agri 16(1): 157-168. DOI: http:// dx.doi. org/10.3329/sja.v16i1.37431

Sharma I (2009) Economics of true potato seed and conventional potato cultivation practices in Rupandehi district, Nepal. M.Sc. Thesis, IAAS, Rampur, Chitwan, Nepal. pp. 4044.

Subedi S, Ghimire YN, Gautam S, Poudel HK and Shrestha J (2019) Economics of potato (Solanum tuberosum L.) production in terai region of Nepal. Archives of Agriculture and Environmental Science 4(1): 57-62.

Wongnaa CA and Ofori D (2012) Resource-use efficiency in cashew production in Wenchi Municipality, Ghana. Agris On-line Papers in Economics and Informatics 4: 73-80.

Wosor DK and Nimoh F (2012) Resource use efficiency in chili pepper production in the Keta municipality of Volta Region of Ghana. J. Elixir Prodn. Mgmt. 47: 8595-8598. 